\title{
Equilibrium between resources and expenditure of health sector of Social Security Fund: a case study of Iran
}

Azadeh Ahmadi Dashtian ${ }^{1}$, Mohsen Mardali ${ }^{2}$

Sama Technical and Vocational Training College, Islamic Azad University, Qaemshahr Beranch, Qaemshahr, Iran

Department of Health Services Management, School of Management and Economics, Science and Research Branch, Islamic Azad University, Tehran, Iran

\begin{abstract}
In Iran, Social Security is the most important institution of social insurance fund, currently insuring more than a half of country population, and it has a significant role in fulfilling short-term and long-term commitments. Therefore investigation of the balance of resources and expenditure of health sector of the fund can be a scientific process of the funding the future and can pave the way to provide necessary revisions in this sector. Analyzing equilibrium between resources and expenditure of health sector of Social Security Fund in the past years, the present study offers recommendations for improving it in terms of parametric and structural dimensions. The methodology includes documentary library methods and statistical part is descriptive using Excel. Findings indicated that, regarding the present lack of balance of resources and expenditure of health sector, keeping on with the present conditions can lead to many crises. As a result, to escape from the present conditions of the funds where lack of balance of resources and expenditure exists, carrying out parametric and management-structural revisions seems necessary.
\end{abstract}

Keywords

Insurance; Social Security; Iran; Resources, Expenditure

\section{INTRODUCTION}

Social Security Fund is the main, largest and most developed institute of social security in Iran. It has been formed in a 50-year period of social and economic change and became active after the publication of the Social Security Bill in 1975. The article 1 of Social Security Law states that «For the purpose of implementing, extending and expanding various types of social insurance, and developing a consistent system appropriate to social security requirements, as well as centralizing cashes and incomes subject to the Social Security Law and investing and exploiting funds and resources, an independent Organization, affiliated with the Ministry of Social welfare, called the "Social Security Organization", is established» [1]. Nowadays, this institute is responsible for insuring more than half of country population and it has an influential role in the insurance system of the country [2]. The investigation of the balance between resources and expenditure of health sector of this institute is fundamental to draw a trend of the Fund in the future and enable management decisions in this sector. The aim of the present study is to analyze the equilibrium between resource and expenditure in the health sector of the Social Security Fund in the past years and to suggest some recommendations for its improvement.

\section{Evolution of Social Security System in Iran}

With the advent of industrialization, fast economic and social growth led to creation of rules and organizations to meet health and social needs of employers and workers in different sector. The first step was the introduction of a set of methods and guidelines in 1930 , followed by a precaution part in factories and institutes in 1936, the institution of a social insurance in 1968, and the launch of Social Security Fund in 1975.

In 1979, the revision of 1975 Social Security Bill led to the integration of Social Security
Corresponding author Azadeh Ahmadi Dashtian dashtiyan.a.a@gmail.com

Disclosure

The authors declare they have no competing financial interests concerning the topics of this article 


\begin{tabular}{|c|c|c|c|c|c|}
\hline Year & Main insured & Pensioners & $\begin{array}{l}\text { Sum of insured } \\
\text { people and } \\
\text { pensioners }\end{array}$ & $\begin{array}{c}\text { Employees } \\
\text { in the insurance } \\
\text { company }\end{array}$ & $\begin{array}{l}\text { Ratio of insured people } \\
\text { and pensioners to } \\
\text { employees }\end{array}$ \\
\hline 1962 & 206,120 & 12,111 & 218,241 & 2,782 & 112 \\
\hline 1963 & 309,596 & 14,107 & 222,702 & 3,262 & 99 \\
\hline 1964 & 312,416 & 18,232 & 331,046 & 3,228 & 96 \\
\hline 1965 & 229,026 & 20,999 & 249,625 & 2,658 & 96 \\
\hline 1966 & 294,812 & 23,913 & 418,726 & 2,002 & 105 \\
\hline 1967 & 351,578 & 26,900 & 478,278 & 4,445 & 108 \\
\hline 1968 & 539,862 & 27,738 & 567,700 & 5,207 & 109 \\
\hline 1969 & 627,017 & 31,256 & 658,273 & 6,218 & 106 \\
\hline 1970 & 683,396 & 33,850 & 717,326 & 7,092 & 101 \\
\hline 1971 & $7,022,017$ & 37,483 & 769,500 & 7,999 & 96 \\
\hline 1972 & 722,584 & 41,022 & 874,616 & 9,285 & 94 \\
\hline 1973 & $1,001,740$ & 44,036 & $1,045,776$ & 10,328 & 100 \\
\hline 1974 & $1,122,911$ & 49,679 & $1,172,586$ & 12,074 & 97 \\
\hline 1975 & $1,289,791$ & 53,892 & $1,343,682$ & 13,180 & 102 \\
\hline 1976 & $1,520,951$ & 61,201 & $1,582,152$ & 3,930 & 404 \\
\hline 1977 & $1,688,310$ & 69,633 & $1,757,952$ & 2,001 & 239 \\
\hline 1978 & $1,765,526$ & 79,372 & $1,844,898$ & 6,500 & 284 \\
\hline 1979 & $1,811,736$ & 89,104 & $1,900,820$ & 6,700 & 284 \\
\hline 1980 & $1,697,978$ & 100,903 & $1,798,381$ & 6,800 & 263 \\
\hline 1981 & $1,727,573$ & 125,287 & $1,852,852$ & 7,068 & 262 \\
\hline 1982 & $1,746,740$ & 153,776 & $1,900,516$ & 7,013 & 271 \\
\hline 1983 & $1,758,319$ & 171,590 & $1,929,909$ & 6,896 & 280 \\
\hline 1984 & $1,973,615$ & 184,661 & $2,158,276$ & 6,643 & 225 \\
\hline 1985 & $2,121,012$ & 196,088 & $2,317,100$ & 6,649 & 248 \\
\hline 1986 & 223,397 & 211,149 & $3,434,546$ & 7,170 & 339 \\
\hline 1987 & $1,956,514$ & 229,553 & $3,186,067$ & 7,094 & 308 \\
\hline 1988 & $2,180,390$ & 238,871 & $2,429,211$ & 7,102 & 242 \\
\hline 1989 & $2,423,974$ & 273,819 & $2,697,793$ & 7,370 & 366 \\
\hline 1990 & $2,779,138$ & 313,638 & $3,092,776$ & 7,296 & 420 \\
\hline 1991 & $2,978,457$ & 340,870 & $2,219,327$ & 10,153 & 327 \\
\hline 1992 & $3,318,192$ & 365,962 & $3,684,156$ & 10,822 & 340 \\
\hline 1993 & $3,579,270$ & 410,315 & $2,990,285$ & 11,829 & 227 \\
\hline 1994 & $3,894,654$ & 472,254 & $3,368,008$ & 13,159 & 332 \\
\hline 1995 & $4,220,725$ & 515,367 & $4,746,092$ & 13,297 & 352 \\
\hline 1996 & $4,819,859$ & 554,654 & $9,374,514$ & 11,697 & 392 \\
\hline 1997 & $5,100,535$ & 588,392 & $5,688,927$ & 14,222 & 400 \\
\hline 1998 & $5,625,038$ & 617,830 & $6,242,868$ & 14,815 & 221 \\
\hline 1999 & $5,849,456$ & 653,916 & $6,502,972$ & 12,768 & 449 \\
\hline 2000 & $5,943,708$ & 692,321 & $6,638,029$ & 15,082 & 440 \\
\hline 2001 & $6,059,167$ & 726,336 & $6,785,503$ & 16,612 & 408 \\
\hline 2002 & $6,257,913$ & 774,794 & 733,277 & 166,655 & 428 \\
\hline 2003 & $6,578,249$ & 835,471 & $7,413,723$ & 16,892 & 439 \\
\hline 2004 & $6,888,154$ & 917,569 & $7,805,723$ & 16,822 & 464 \\
\hline 2005 & $7,161,767$ & 957,053 & $8,118,920$ & 16,622 & 488 \\
\hline 2006 & $7,373,727$ & $1,058,853$ & $8,533,579$ & 17,229 & 495 \\
\hline 2007 & $7,512,054$ & $1,144,582$ & $8,656,606$ & 18,580 & 466 \\
\hline 2008 & $8,412,492$ & $1,237,091$ & $9,689,583$ & 20,872 & 464 \\
\hline 2009 & $9,152,242$ & $1,340,444$ & $10,392,687$ & 19,441 & 540 \\
\hline 2010 & $9,917,542$ & $1,255,166$ & $1,272,708$ & 19,023 & 598 \\
\hline 2011 & $10,573,705$ & $1,552,096$ & $12,125,801$ & 18,995 & 638 \\
\hline 2012 & $11,497,089$ & $1,726,457$ & $12,222,546$ & 17,942 & 737 \\
\hline $\begin{array}{l}\text { Average } \\
\text { growth }\end{array}$ & 7.5 & 10.4 & - & 3.8 & 3.8 \\
\hline
\end{tabular}

Table I. Some critical indexes for the functions of Social Security Fund from 1961 to 2012 [5] 
sections into an independent organization affiliated with the Ministry of Welfare. Finally, after the introduction of the "requirement act" in 1989 and its implementation in 1990, Social Security Fund was announced to be responsible for carrying out all commitments mentioned in clauses A and B of Social Security Act [3].

In the note 10 of article 4 of the 1986 implementation bylaw of single-article act announced that optional insured people and selfemployers can use health services by paying only $9 \%$ of insurance fee. Article 9 of "general insurance" reduced this fee to capitation of health and the difference amount would be paid by the government. After the introduction of the "requirement act" in 1989 and its implementation bylaw in 1990, all health services would be carried out by healthcare centers, governmental sector or, if required, by private sector and related expenditure would be paid by the healthcare provider which is the subject of article 29 and other resources with some slight differences in insurance fees [4].

Social Security Organization is a non-governmental public organization and much of its funding comes from contributions and investment profits. Fund's expenditure include legal and processing obligations. The mandatory insurance premium payment is $30 \%$ of the wage of the worker. The employer is responsible for $20 \%$ while government is responsible for $7 \%$ and $3 \%$ of it. Optional insurances range between 14 and $16 \%$ of the wage based on the services they offer.

Legal obligations include long-term (retirement costs, disability pension, remained pension, secondary aids and disability compensation) and short-term commitments (wage compensation when being ill or pregnant, marriage financial aids, burial costs, etc.) Eighteen percent of $30 \%$ which is received as the insurance fee is dedicated to long-term commitments, $9 \%$ is dedicated to treatment of insured people and 3\% is dedicated to short-term services [2].

The main sponsor of the fund is the triple cooperation of employers, insured people and the government in different fields such as macro-decisions and providing financial supports. The commitment of this organization equals to standards of 'International Labor Organization' and 'International Organization of Social Security' and methods of performing these services are based on fundamentals of 'Social Security Law' [3].

\section{Macro-condition of Social Security Fund}

The ratio of overall expenditure to all the resources of Social Security Fund has been increased from $45 \%$ in 1976 to $96 \%$ in 2005 (Table I). Analyzing this ratio, it must be said that when it approaches 1, it indicates crisis of the fund. In addition, the ratio of long-term expenditure to overall expenditure was 7 to 9 in 1976 and the ratio of long-term expenditure to resources obtained from insurance fee was 65 to 78 in 2010. However, the ratio of costs of legal obligation store sources has passed its peak in 2010. Information of replacement ratio shows a normal situation in this fund; i.e. when this ratio is raised, welfare of retired people increases and it encourage employees to get retired due to lack of difference between incomes when employed or retired; in this sense, outcome and expenditure of the fund would increase [4].

The average growth of the number of insured people, pensioner and ratio of insured people and pensioners to employees working in Social Security Fund was, respectively $7.5 \%$, $10.4 \%$ and $3.8 \%$ from 1976 to 2011 . This indicates an improvement of the growth rate of pensioners in this fund [5].

Ratio of correlation (for each pensioner there is a number of people who pay insurance fees) had a decreasing trend from 1976 to 2011 (from $25.8 \%$ to $6.6 \%$ ), despite attempts to perform programs to improve the number

\begin{tabular}{lcc}
\hline & $\begin{array}{c}\text { Insured } \\
\text { people (n.) }\end{array}$ & $\begin{array}{c}\text { Growth rate compared } \\
\text { to the previous year (\%) }\end{array}$ \\
\hline Insured people (main) & $13,278,629$ & 4.6 \\
Insured people (dependent) & $21,675,494$ & 2.3 \\
Insured people (main + & $34,954,123$ & 3.2 \\
dependent) & & \\
Pensioner (main) & $2,738,587$ & 8.4 \\
Pensioner (dependent) & $2,307,439$ & 5.4 \\
Pensioners (main + dependent) & $5,046,026$ & 7.0 \\
Total & $40,000,149$ & 3.6 \\
\hline
\end{tabular}

Table II. Number of insured people (December 2014) [5]

\begin{tabular}{lc}
\hline \multicolumn{1}{c}{ Index } & Amount \\
\hline Ratio of support & 6.20 \\
Share of mandatory insured people among all insured people (\%) & 69.37 \\
Share of optional insured people among all insured people (\%) & 5.82 \\
Share of insured drivers among all insured people (\%) & 7.90 \\
Share of insured weavers among all insured people (\%) & 4.10 \\
Share of agreed insured people among all insured people (\%) & 1.64 \\
Share of unemployed insured people among all insured people (\%) & 1.25 \\
Share of insured workers among all insured people (\%) & 5.00 \\
Share of retired people among all pensioners (\%) & 63.98 \\
Share of disabled people among all pensioners (\%) & 30.22 \\
\hline
\end{tabular}

Table III. Important statistics in insurance section in 2014 [5] 
of insured people (including mandatory insurance and self-employers), and a further decrease in $2014(6.2 \%)$ [5]

Table II and Table III show the number of insured people and some statistics related to year 2014.

\section{Health sector of Social Security Fund}

Khadamat-e-darmani (Healthcare Insurance Company) is an important part of social insurances which has a crucial and decisive role in providing health. Social Security Fund is responsible for Healthcare Insurance Company, most important activities of which include implementation, generalization, and development of different social insurances all over the country. Reaching this goal, which is a pre-requisite to maintenance and development of health is possible when it obviously fulfill needs. The driving force for performing activities in the health sector is its resources like in any other businesses. Employing these resources - called expenditure - would make reaching goals possible. Reaching goals of health sector is possible only when resources and expenditure are clearly defined and their applications are diagnosed in accordance with their related uses so as to make the development of their optimal utilization possible. Also, in this way, necessary information would be presented to managers and policy makers [5].

In this investigation, attempts are made to analyze resources and legal expenditure of health sector from 1980 to 2012. To this scope, resources and expenditure of health

\begin{tabular}{lc}
\hline \multicolumn{1}{c}{ Item } & Amount \\
\hline Direct treatment & \\
Average active bed (n.) & 9,073 \\
Used beds (\%) & 74 \\
Death (n. in 1000) & 8 \\
Average patient's stay (day) & 2.7 \\
Return period (hour) & 23 \\
Bed change (n.) & 74 \\
Hospitalized people in Tamin-e-ejtemaei Insurance (\%) & 79.5 \\
Indirect treatment & \\
Contracted hospitals (\%) & 13.5 \\
Treatment center and contracted policlinics (\%) & 28.9 \\
Contracted D-clinics (\%) & 7.1 \\
Contracted health centers & 55.9 \\
Average rate of hospitalization (Rials) & 118,150 \\
Average expense of hospitalization (Rials) & 7.812 .966 \\
\hline
\end{tabular}

Table IV. Indexes related to direct and indirect treatment in 2014 [5] sector (Table IV) have been defined from 1980 to 2013 based on inventories of the organization in each year and change trend of them have been presented in current expenses, changes in inventories in the health sector and health expenses and their relationship with economic macro-indexes are explained.

\section{Defining concepts related to resources and expenditure}

Legal resources: all financial processes entering health sector in the financial period based on legal obligations and account documents or changes leading to increase of investments and debts or to decrease of property.

Legal expenditure: all financial processes exiting health sector in the financial period based on legal obligations and account documents or changes leading to increase of property or to decrease of investments or debts.

Treatment investment: extra income other than treatment expenses saved in an account with the title of 'treatment investment' (Annual yearbook of Social Security Organization, 2013).

\section{RESULTS AND DISCUSSION}

\section{Resources}

Treatment incomes were 212,912 million Rials ( 1 IRR $=0.0000252048$ EUR [6]) in 1980, 171,457 million Rials in 1990, 292,576 in 1994 and 519,604 in 2001 at constant prices. Average annual growth rate of treatment incomes was $0.5 \%$ in the first period (1980-1985), 5.3\% in the second period (1986-1989), 16.3\% in the third period (1990 - 1993), 5.9\% in the fourth period (1994 - 1997) and $11.3 \%$ in the fifth period (1998 - 2001). In order to come to a more realistic growth trend of treatment incomes, the trend of annual income inflation rate is not included.

Annual treatment income was 31,524 million Rials in 1980, 13,656 million Rials in 1990, 15,626 million Rials in 1994, and 19,607 million Rials in 2001. Also, average annual growth rate was $5 \%, 10.4 \%, 6.2 \%$, $2.1 \%$, and $7.9 \%$ for the first, second, third, fourth, and fifth period, respectively. Treatment reserves at constant prices always had a positive growth and the annual growth in the third period was $53 \%$ ( $70.5 \%$ at current prices), $24.2 \%$ in the fourth period (compared to $48.8 \%$ ) and $9.4 \%$ (compared to $32.4 \%$ ) in the fifth period. Health sector debts at fixed prices also had a slower upward trend from 38,644 million Rials in 1991 to 67,345 million Rials in 1994 and to 161,320 million Rials in 2001. 


\begin{tabular}{cccccc}
\hline Year & $\begin{array}{c}\text { Total treatment } \\
\text { costs (Rials) }\end{array}$ & $\begin{array}{c}\text { Direct treatment } \\
\text { costs (Rials) }\end{array}$ & $\begin{array}{c}\text { Direct treatment } \\
\text { costs on total } \\
\text { costs (\%) }\end{array}$ & $\begin{array}{c}\text { Indirect } \\
\text { treatment costs } \\
\text { (Rials) }\end{array}$ & $\begin{array}{c}\text { Indirect } \\
\text { treatment costs } \\
\text { on total costs (\%) }\end{array}$ \\
\hline 1991 & 92,858 & 31,615 & 34 & 61,243 & 66 \\
1992 & 180,600 & 53,681 & 29.7 & 126,919 & 70.3 \\
1993 & 294,552 & 84,609 & 28.7 & 209,943 & 71.3 \\
1994 & 386,694 & 112,812 & 29.2 & 273,882 & 70.8 \\
1995 & 517,053 & 164,805 & 31.9 & 352,248 & 68.1 \\
1996 & 717,941 & 227,222 & 31.6 & 490,719 & 68.4 \\
1997 & $1,109,982$ & 350,118 & 31.5 & 759,864 & 68.5 \\
1998 & $1,560,803$ & 485,667 & 31.1 & $1,075,136$ & 68.9 \\
1999 & $2,092,449$ & 591,891 & 28.3 & $1,500,558$ & 71.7 \\
2000 & $2,422,064$ & 751,388 & 31 & $1,670,676$ & 69 \\
2001 & $3,197,183$ & $1,148,143$ & 35.9 & $2,049,040$ & 64.1 \\
2003 & $4,350,686$ & $1,575,217$ & 36.2 & $2,775,469$ & 63.8 \\
\hline
\end{tabular}

Table V. Share of expenditure from 1990 to 2002 [4]

\section{Expenditure}

The growth in treatment expenses at fixed prices had also an increasing trend from 185,082 million Rials in 1980 , to 192,858 , 207,401 , and 454,427 million Rials in 1990, 1994, and 2001, respectively. Average annual growth of these expenses was $-9.9 \%$ in the first period, $-3.2 \%$ in the second period, +19.8 in the third period, $+9.3 \%$ in the fourth period, and $12.5 \%$ in the fifth period.

Annual treatment expenses were 27,403 Rials in 1980, 7,396 Rials in 1990, and 11,078 Rials in 1994 and 17,148 Rials in 2001. Average annual growth was $-15.1 \%$ for the first period, $8.1 \%$ for the second period, $9 \%$ for the third period, $0.9 \%$ for the fourth and $8.8 \%$ for the fifth period.

Total value of properties at fixed costs increased from 157,558 million Rials in 1980 to 359,749 million Rials in 1990 and to 859,780 in 2001 . Average annual growth was $19.6 \%, 22.9 \%$, and $9.8 \%$ in the third, fourth and the fifth period, respectively.

\section{Extra amount of incomes and expenses}

Extra incomes and expenses are functions of changes in incomes and expenses and calculation of them at fixed costs show their real changes in related years. Extra amount of income at fixed prices was 78,599 million Rials in 1990, 85,175 million Rials in 1994 and 5,177 million Rials in 2001.

If extra amounts capitation is considered as a criterion for the evaluation of health sector, then extra capitation was 6,260 Rials in 1990, 4,550 Rials in 1994, 1,433 Rials in 1998 and 2,459 million Rials in 2001. Average annual growth was $29.8 \%, 10.8 \%$, and $14.5 \%$ in the third, fourth, and fifth period, respectively. Due to unavailability of data about resources and expenses of the organization at fixed prices from 2002 to 2013, those information are not reported in this analysis.

Since 1990 a greater portion of the treatment expenditure has been allocated to direct treatment and, as shown in Table V, the share of direct treatment expenditure increased to $30.3 \%$ in the third period (1990 - 1993), to $31.5 \%$ in the fourth period (1994 - 1997) and to $32.8 \%$ in the fifth period (1998 - 2001). Inversely, indirect treatment costs reduced from $69.6 \%$ in the third period to $68.5 \%$ in the fourth and to $67.1 \%$ in the fifth period. In 2002, the share of direct treatment expenditure was $46.7 \%$ and share of indirect treatment expenses was $53.3 \%$ of total expenditure.

Table VI shows the share of direct and indirect treatment expenditure after the requirement act.

A great share of treatment expenditure come from the increase of costs in related years. The omission of inflation of growth rate of expenditure shows their real growth. In the analyzed periods, treatment expenditure

\begin{tabular}{ccc}
\hline Period (year) & $\begin{array}{c}\text { Indirect treatment } \\
\text { expenditure (\%) }\end{array}$ & $\begin{array}{c}\text { Direct treatment } \\
\text { expenditure (\%) }\end{array}$ \\
\hline 1991- 1994 & 69.6 & 30.3 \\
1995- 1998 & 68.5 & 31.5 \\
1999- 2002 & 67.1 & 32.8 \\
2003 & 55.9 & 44.1 \\
\hline
\end{tabular}

Table VI. Share of direct and indirect treatment expenditure in years after 'requirement act' [4] 


\begin{tabular}{lcc}
\hline & $\begin{array}{c}\text { Growth in } \\
\text { treatment } \\
\text { expenditure (\%) }\end{array}$ & $\begin{array}{c}\text { With omission } \\
\text { of inflation from } \\
\text { expenditure (\%) }\end{array}$ \\
\hline First period (1980-1984) & 7.6 & 9.9 \\
Second period (1985-1990) & 14.5 & 3.2 \\
Third period (1991-1994) & 44 & 19.8 \\
Fourth period (1995-1998) & 41.9 & 9.3 \\
Fifth period (1999-2002) & 29.4 & 12. \\
\hline
\end{tabular}

Table VII. Growth rate in treatment expenses from 1979 to 2002 [4]

grew from $7.6 \%$ in the first period, to $29.4 \%$ in the fifth period (Table VII).

\section{Trend of resources and expenditure at current price}

In Appendix A resources and expenditure of health sector of Social Security Fund at current price from 1979 to 2014 are reported. Based on Authors' calculations, between 1975-2014, resources, expenditure, and total income of the organization grew up of $9 \%$, $13 \%$ and $28 \%$, respectively.

Figures 1 and 2 show the trend of expenditure and resources indexes of health sector of Social Security Fund between 1980-2014.

As shown in Table VIII, the Social Security Fund ratio of participation in the health sec-

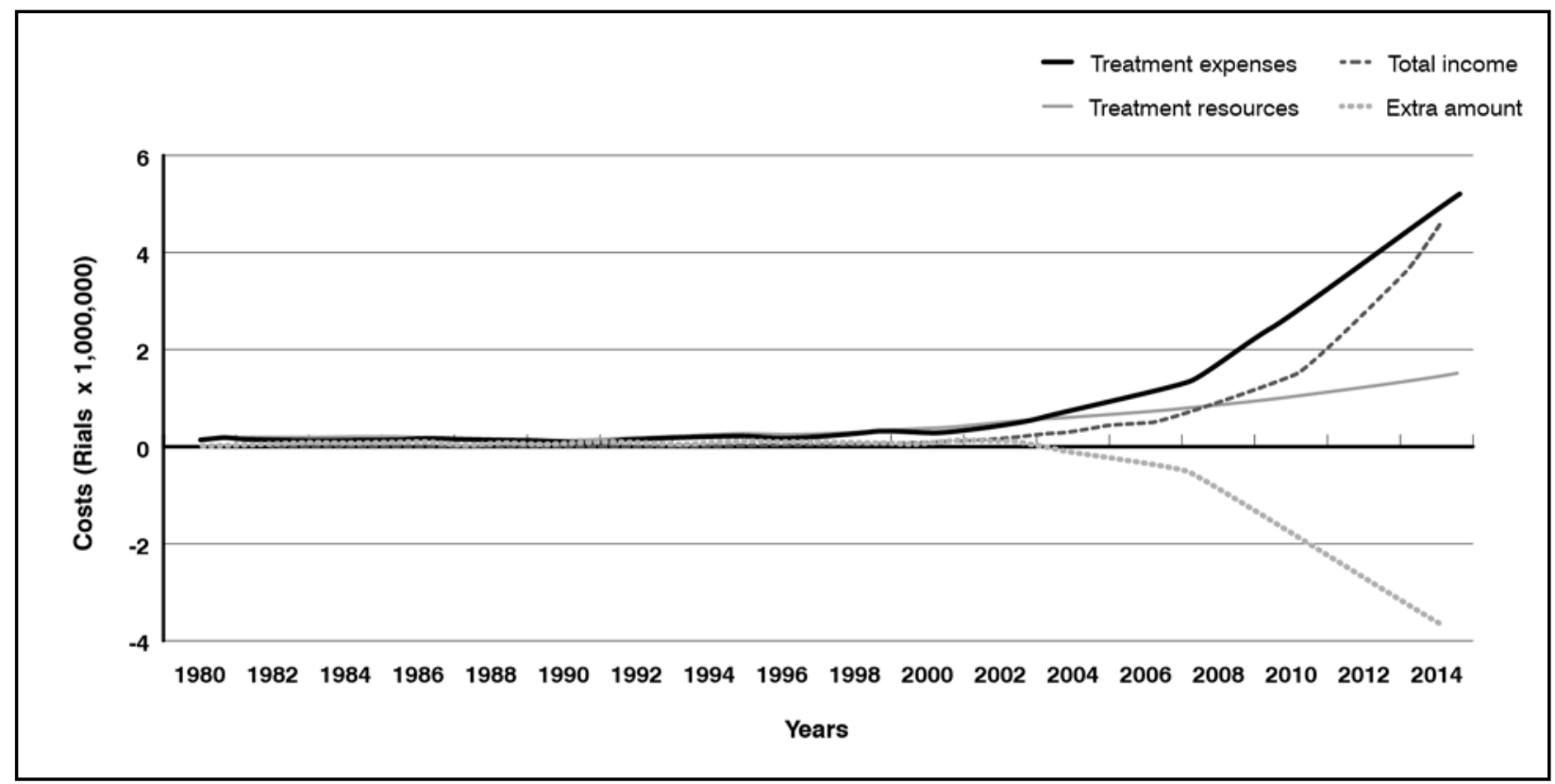

Figure 1. Trend of treatment expenditure and resources, total income of the organization, and Extra amount (resources - expenditure) from 1980 to 2014

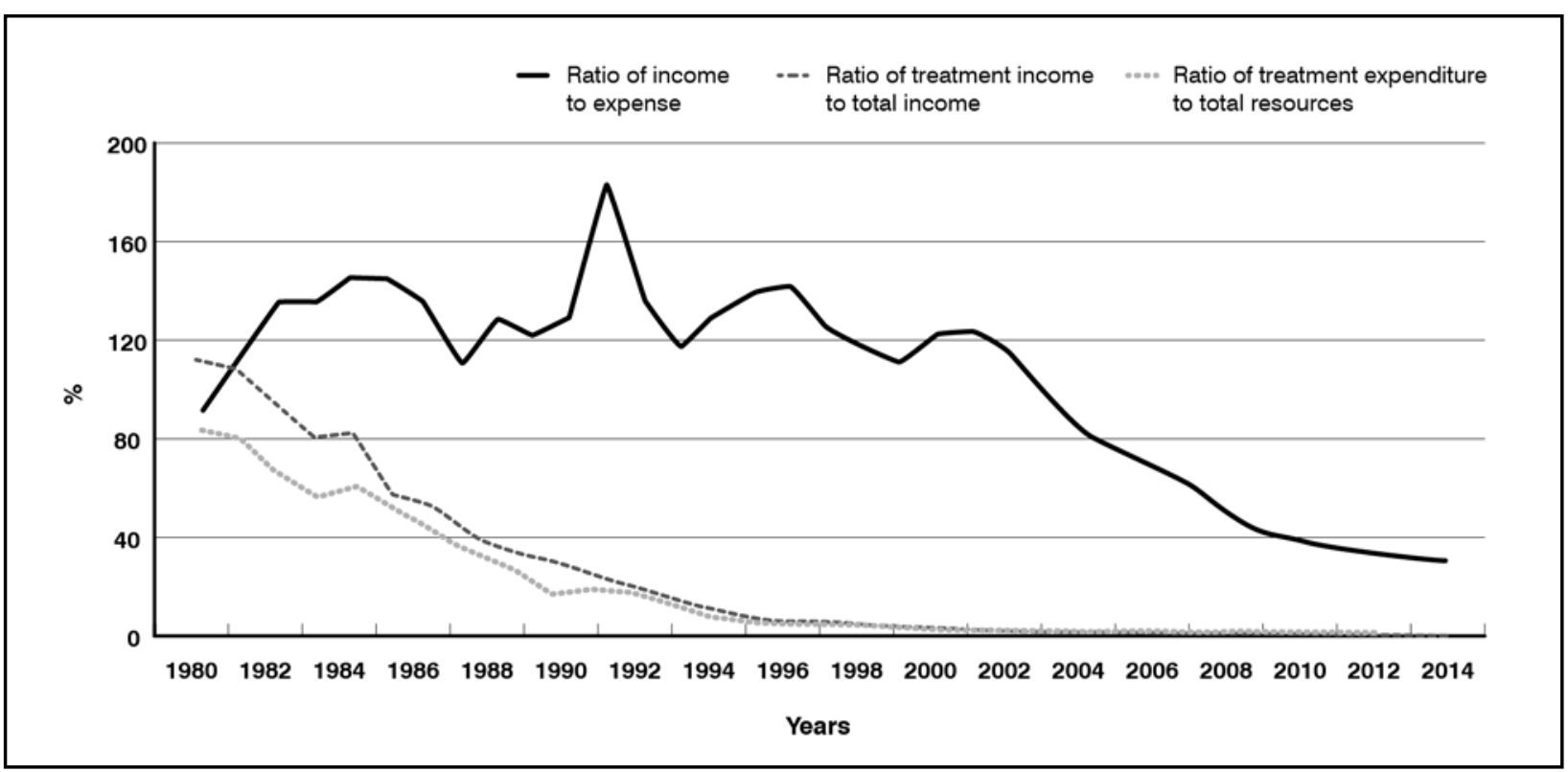

Figure 2. Ratio between resources and expenditure, treatment resources and total income, and treatment expenditure and total income of the organization from 1980 to 2014 
tor expenditure of the Country ranged from 9 to $11 \%$ in years $2002-2011$.

\section{Changes in resources and expenditure of health sector and price fluctuations}

As it can be seen, a large part of the growth of resources and expenditure is due to a constant increase of prices (inflation). If price increases are subtracted from the growth of resources and the cost of treatment is removed remove, actual prices would be available. Figure 3 shows the inflation rate in the health sector in urban and rural areas from 2003 to 2014

Without taking inflation into account, the rate of actual growth would be $0.5 \%$ for the first period (compared to $20.8 \%$ ), $-5.3 \%$ for the second period (as compared to 12.3\%), 16.3\% for the third period (compared to 38.7), 5.9\% for the fourth period (compared to $38.15 \%$ ), 11.3 for the fifth period (compared to $28.4 \%$ ), and finally for the sixth period (2002 - 2013) it is equal to $-3 \%$.

Average rate of actual annual growth would be $9.9 \%$ for the first period (compared to $7.6 \%$ at fixed prices), $-3.2 \%$ for the second period (as compared to $14.5 \%$ ), $19.8 \%$ for the third period (compared to 44\%), 9.3\% for the fourth period (compared to $41.9 \%$ ), $12.5 \%$ for the fifth period (compared to $29.4 \%$ ), and finally for the sixth period (2002 - 2013) it is equal to $7 \%$.

\section{CONCLUSIONS}

As it is observed, according to the present data and statistics, the trend of resources and expenditure of health sector of Social Secu-

\begin{tabular}{cccc}
\hline Year & $\begin{array}{c}\text { Total public } \\
\text { expenditure of health } \\
\text { sector (billion Rials) }\end{array}$ & $\begin{array}{c}\text { Total expenditure } \\
\text { of Social Security } \\
\text { Fund (billion Rials) }\end{array}$ & $\begin{array}{c}\text { Ratio of } \\
\text { participation } \\
\text { (\%) }\end{array}$ \\
\hline 2003 & 53,351 & 5,047 & 9 \\
2004 & 70,222 & 6,580 & 9 \\
2005 & 90,534 & 9,160 & 10 \\
2006 & 116,645 & 12,015 & 10 \\
2007 & 141,667 & 13,154 & 9 \\
2008 & 179,332 & 17,946 & 10 \\
2009 & 224,359 & 24,529 & 11 \\
2010 & 286,327 & 28,000 & 10 \\
2011 & 359,286 & 32,948 & 9 \\
2012 & 452,793 & 39,224 & 9 \\
\hline
\end{tabular}

Table VIII. Social Security Fund ratio of participation in the health sector expenditure [7]

rity Fund needs more considerations. Trend of of resources and expenditure of health sector is a function of total resources of the organization. Therefore, growth of treatment incomes has a negative status when compared to inflation and this due to 1 ) a reduction in organization income in recent years, 2) a little growth of resources, 3) no full allocation of legal resources to this section, 4) no payment of government debts to this sector (near 10000 milliard Rials), 5) growth of long-term commitments of this organization, and 6) reducing trend of number of years of being insured for aims of retirement. On the other hand, expenditure in the health sector would have an upward increasing trend due to many reasons including the semi-insurance (support) acts, the lack of principles of insurance calculations, increasing age of the insured people, increasing number of retired people and the

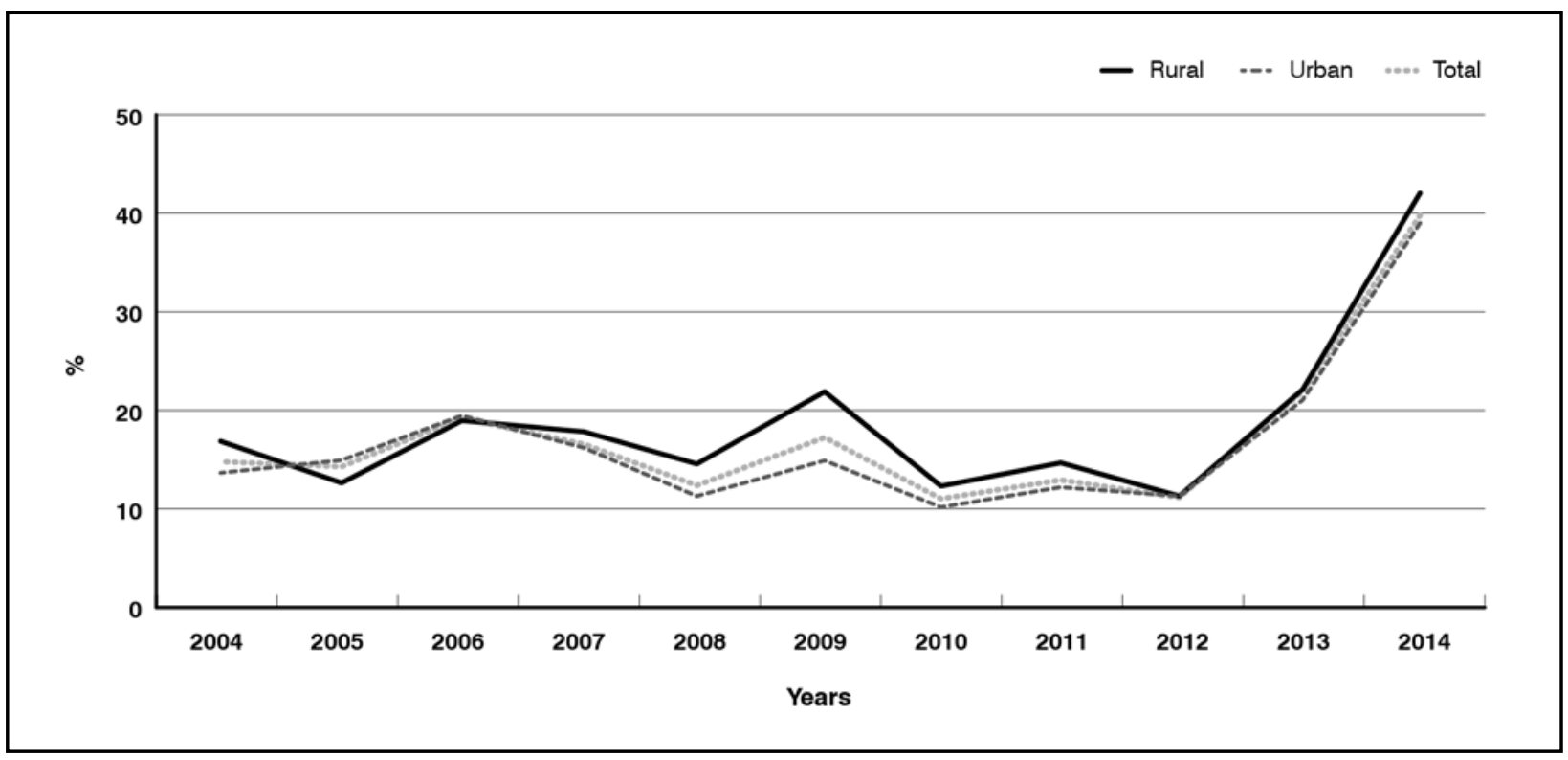

Figure 3. Rate of inflation in health sector from 2003 to 2014 
need to more healthcare services, promotion of health culture in the society in requesting more healthcare services, more request for direct healthcare sector, increase of inflation in production sector, more life expectancy, and lack of investment in prevention of different levels. Now, because of the imbalance of resources and expenditure in the health sector has passed its peak in 2002 as a result of total resources and expenditure of the Organization. Since then, the gap between these has become bigger according to a $9 \%$ growth of resources and 13\% growth of expenditure. On the other hand, the statistical drawback in lack of clarity in the allocation of resources in health sector leads to lack of attention to this problem and this emerges from 1) incorrect discrimination of these numbers and 2) lack of an independent official unit in health sector of Social Security Fund. If this upward trend of the ratio between expenditure and resources persists the imbalance in the health sector would lead to its bankruptcy, dysfunction in the execution of its short-term and long-term commitments, and if not supported by the government it could lead to social crisis.

\section{RECOMMENDATIONS}

Strategies to get out of the present situation to reach an equilibrium between resources and expenditure:

1. Performing parametric reforms

- Increasing of retirement age

- Increasing of work experience and years paying insurance fee

- Increasing of insurance capitation

- Carrying out exact actuarial calculations and readjusting of insurance conditions

- Revising some obligations such as hard work in some occupations and early retirement
2. Carrying out management-structural reforms

- Designing a multi-layer system for Social Security Fund

- Increasing number of insured people

- Saving unnecessary costs

- Paying pending debts

- Paying attention to health of insured people and concentrating on prevention of getting sick

- Lack of imposition of non-insurance commitments such as supportive services by the parliament and the government

- Actual independence of the organization as a supporting non-governmental institute

- Following triple principle so as to attracting cooperation of all beneficiaries in maintenance of the fund

- Preventing methods of escaping from being insured

- Receiving deductible can pave the way to better services of the fund provided to insured people so as to prevent extra costs

- Increasing skills and making employees competent besides reducing unemployment insurance are the best methods of making the fund out of the crisis of correct management financial resources in the organization

- Correct management in organizations offering health services

- Necessary monitor for reducing moral dangers in insurance companies

- Reducing treatment expenditure by prioritizing prevention services and increase of attention to health sector

- Clarity and discrimination of resources in health sector of Social Security Fund and of the trend and behavior of situationsensitive variables

\section{REFERENCES}

1. Islamic Republic of Iran. Social Security Law 1975

2. Fazaeli A, Mehr Ara M. Examining the balance in financial provision of Iranian family `s health expenses. Health Management Journal 2010; 50: 63-70

3. Islamic Republic of Iran. Law of social security organization 1990

4. Shapourgan M. Investigation of resources and expenditure of health sector from 1975 up to now based on rules. Higher institute of Social Security Research, plan and budget: Tehran, 2013

5. Annual year book of Social Security Organization. Available at: https://www.amar.org.ir/english/Iran-StatisticalYearbook

6. XE Currency Converter. Available at: http://www.xe.com

7. Iranian Statistics Center. National Health Account (2002 - 2011). Available at https://www.amar.org.ir/english/ Statistics-by-Topic/National-accounts 


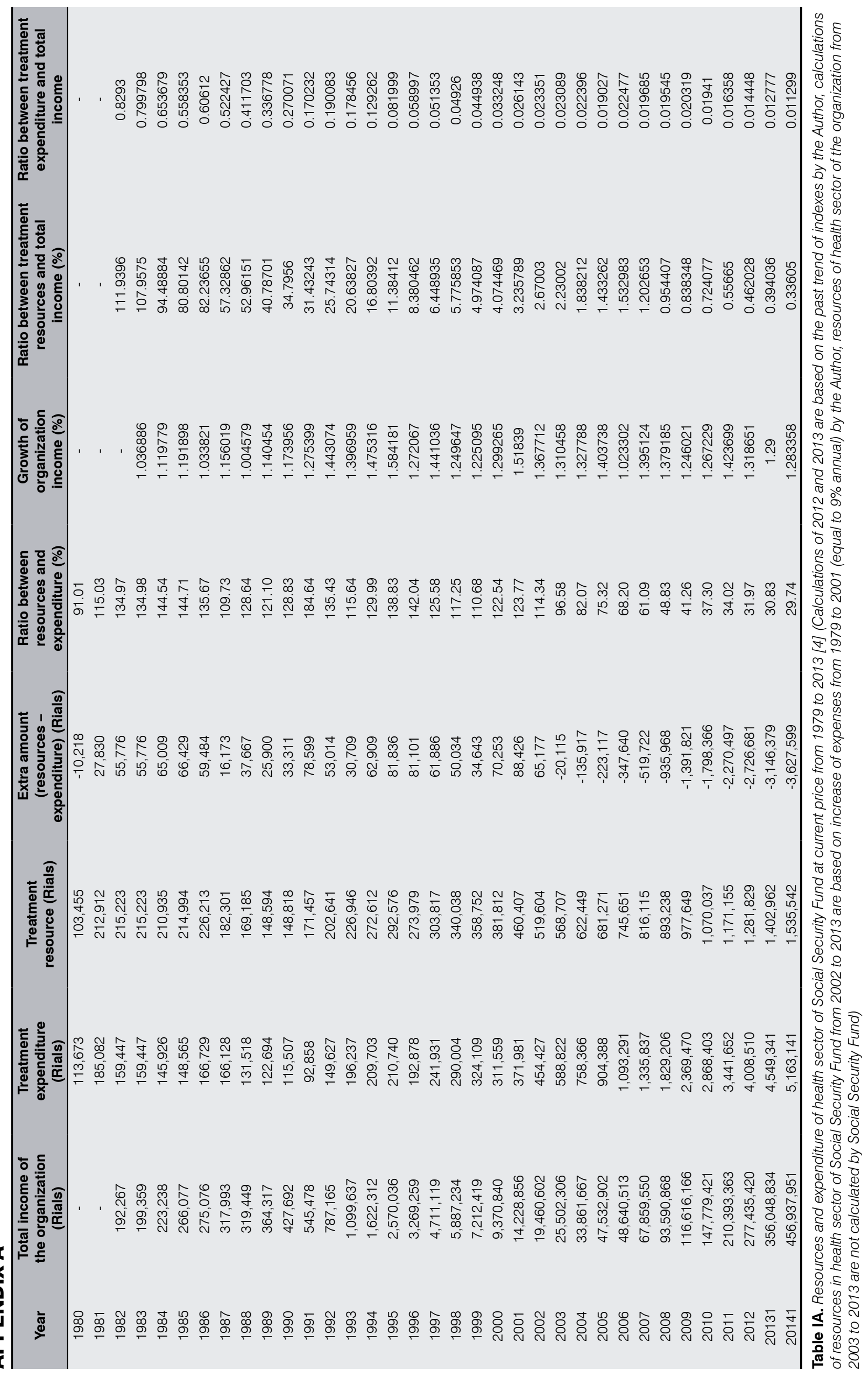

